\title{
Hydrological Performance of Green Roofs
}

\author{
Zuzana Poórová ${ }^{1}$, Zuzana Vranayová ${ }^{2}$, \\ ${ }^{1,2}$ Technical University of Kosice
}

\begin{abstract}
There should be a balance between artificial environment and natural environment. As forests, fields, gardens and urban lands are being replaced with bituminous, concrete and unnatural surfaces, necessity of recovering green and blue spaces and natural areas is becoming more and more critical. Green roof is a tool in strategy of making more pervious areas and beating more impervious areas. Green roof is lately becoming part of urban storm water management. Considering this fact, new construction solutions help green roofs become blue roofs. Typical green roof is becoming an increasingly popular solution of impervious roof top of the building. New construction solutions with temporary water reservoirs help the original green roof become retention blue roof. Storm water management should enable the natural processes to infiltrate, evapo-transpire or capture and use storm water on or near the site, potentially generating other environmental benefits. The water cycle should be managed to close the loop, although this is not always possible. Rainwater needs to be harvested and recycled. Surface water needs to be retained within the site and returned to the land for the recharging of groundwater by means of filtration beds, pervious roadways and built surfaces, retention ponds and bioswales. Water used in the built environment needs to be recovered and reused wherever possible. The aim of this article is to lay out technical specifications of different green roofs in terms of water retention, discharge coefficient and water storage. In this article, different roofs with vegetation on the top of the roofs are described. Diverse roof layers creating diverse roof constructions have different features. Capability of different roofs for catching rainwater, reducing pollutants, compared to typical water runoff, entering watershed and keeping liters out of the city sewer system are one of the main goals of this article. Novelty in co-operation of landscape and dwelling is bringing nature to the city, making green and blue fashionable, making green-blue roof fifth living façade of the building, designing healthy and vegetated towns. Very old method of improving sustainability is introducing green and blue key elements in the environmental strategy.
\end{abstract}

Keywords - Blue, retention, storage, water

\section{INTRODUCTION}

Urban roof is a very challenging place, which offers lofty ideas and potential hectares of green / blue spaces above our cities. Architects, town planners are going back to the green roofs because of many reasons: their beauty, practical effects, ability to resist environmental changes and environmental extremes. They have many ecological aspects such as catching water, unloading surface drainage, preventing building from overheating/cooling, lowering the presence of allergens, dust, protecting roof layers from UV radiation, lowering sound, forming oxygen and capturing $\mathrm{CO}_{2}$, but also many economical, environmental, health, aesthetic and other features $[1,2,3]$.
The aim of this article is to show how much possible green / water areas we could build. The article points at the possibilities that could mean some change for the future generations. In this article, 6 different roofs are described. 1. lightweight roof, 2. economy roof, 3. nature roof, 4. pitched roof A, 5. pitched roof B and 6. retention roof. Each roof layers and technical specifications are described.

This article mainly focuses on each roof's water storage. Water storage of each roof is expressed in liters per $1 \mathrm{~m} 2$. The aim of this article is to show the ability of different roofs to catch water, to point at discharge coefficient and water storage of each roof in question. Exemplary $1 \mathrm{~m}^{2}$ is recalculated into $100 \mathrm{~m}^{2}$ at the end of this article, which could represent a roof of one single family house.

The question this article addresses is what effect would green - blue roofs have on our cities, buildings, environment, lives, and health. How much water would we be able to keep above our heads and what would be the possibilities for us at present and for the future generations.

\section{II.LIGHTWEIGHT ROOF}

TABLE I

LIGHTWEIGHT ROOF LAYERS [4]

\begin{tabular}{|c|c|}
\hline 1 & Optigreen Pre-cultivated Sedum Vegetation Mat Type SM/G \\
\hline 2 & Optigreen Low Density Substrate Type L $\left(30 \mathrm{l} / \mathrm{m}^{2}\right)$ \\
\hline 3 & Optigreen Drainage Board Type FKD 25 $(25 \mathrm{~mm})$ \\
\hline 4 & Optigreen Protection and Storage Fleece Type RMS 300 \\
\hline 5 & Waterproofing membrane \\
\hline 6 & Suitable substructure \\
\hline
\end{tabular}

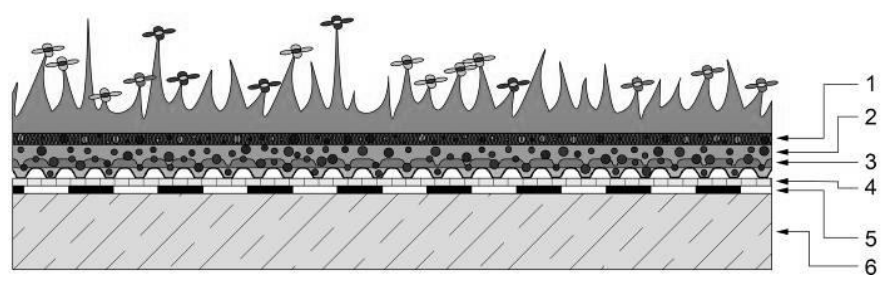

Fig. 1. Lightweight roof [4].

Features of lightweight roof in Fig.2 The lightest green roof solution. Special construction design. Drift-proof system solution, only usable with a secured, fixed roof membrane. Can also be used for non-pitched roofs without deep puddles forming. Available with automatic irrigation systems for dry regions. Increased care requirements and production costs as compared to the Economy Roof. Weight specifications refer to saturated conditions; dry weight is approximately $50-60 \%$ of the saturated weight. Discharge coefficient depends on the slope and system solution [4]. Roof layers in Fig.1 are 
described in Table I and its technical specifications are given in Table II.

TABLE II

LIGHTWEIGHT ROOF TECHNICAL SPECIFICATIONS [4]

\begin{tabular}{|l|l|}
\hline Weight & $53 \mathrm{~kg} / \mathrm{m}^{2}$ \\
\hline Layer height & $50 \mathrm{~mm}$ \\
\hline Roof pitch & $0-5^{\circ}(0-9 \%)$ \\
\hline Vegetation form & moss-sedum \\
\hline Water retention & $40-50 \%$ \\
\hline Discharge coefficient & $\mathrm{C}=0.63-0.65$ \\
\hline Water storage & $181 / \mathrm{m}^{2}$ \\
\hline Ecological value & $\square \square \square \square \square$ \\
\hline Maintenance costs & $\square \square \square \square \square$ \\
\hline Cost factor & $\square \square \square \square \square$ \\
\hline
\end{tabular}

Optigreen Pre-cultivated Sedum Vegetation Mat Type SM/G: Pre-cultivated sedum/moss mat for the fast establishment of vegetation in order to prevent wind erosion, with decomposable lining material.

Optigreen Low Density Substrate Type L $\left(30 \quad 1 / \mathrm{m}^{2}\right)$ : Specialized substrate for single layer extensive construction designs that features low weight but high water storage capacity.

Optigreen Combi Inspection Chamber (not shown in the drawing): Simple control of root drainage outlets. Mounted onto the Optigreen Drainage Board Type FKD 25.

Optigreen Drainage Board Type FKD 25 (25 mm): Rapid discharge of surplus water. Prevents accumulation of water for non-pitched roofs and large drainage lengths. Light-weight build-up with high drainage capacity.

Optigreen Protection and Storage Fleece Type RMS 300: Protects the roof membrane against damage and stores water. For inverted roofs, use the Optigreen Trickle Protection Mat Type RS instead of the RMS fleece [4].

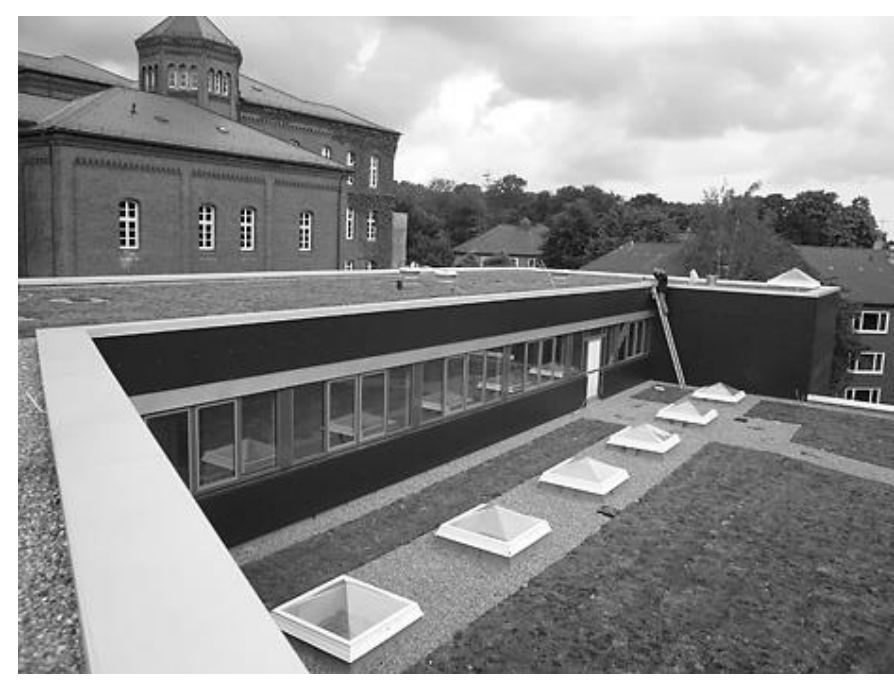

Fig. 2. Lightweight roof [4].

\section{ECONOMY ROOF}

TABLE III

ECONOMY ROOF LAYERS [5]

\begin{tabular}{|l|c|}
\hline 1 & Optigreen Pre-cultivated Sedum Vegetation Mat \\
\hline 2 & Optigreen Extensive Substrate Type E $(60 \mathrm{~mm})$ \\
\hline 3 & Optigreen Filter Fleece Type 105 \\
\hline 4 & Optigreen Drainage Board Type FKD $25(25 \mathrm{~mm})$ \\
\hline 5 & Optigreen Protection and Storage Fleece Type RMS 300 \\
\hline 6 & Waterproofing membrane \\
\hline 7 & Suitable substructure \\
\hline
\end{tabular}

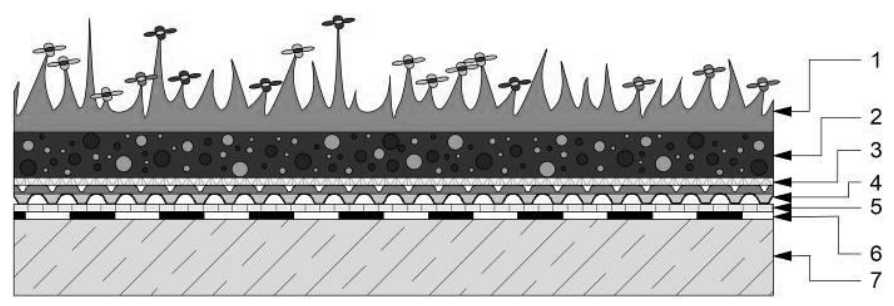

Fig. 3. Technical specifications of economy roof [5].

Features of economy roof in Fig.4 Traditional multi-layered structure including drainage and filter fleece. Particularly affordable roof greening. Low maintenance requirement. Comparably low biodiversity. Generally suitable for the inverted roof; if applicable, minimum load for the wind up-lift protection has to be considered. Weight specifications refer to the saturated conditions; dry weight is approximately $60-70$ $\%$ of the saturated weight. Discharge coefficient depends on the slope and system solution [5]. Roof layers in Fig.3 are described in Table III and its technical specifications are given in Table IV.

TABLE IV

ECONOMY ROOF TECHNICAL SPECIFICATIONS [5]

\begin{tabular}{|l|l|}
\hline Weight & $90-140 \mathrm{~kg} / \mathrm{m}^{2}$ \\
\hline Layer height & $80 \mathrm{~mm}$ \\
\hline Roof pitch & $0-5^{\circ}(0-9 \%)$ \\
\hline Vegetation form & sedum-herbs-grasses \\
\hline Water retention & $50-60 \%$ \\
\hline Discharge coefficient & $\mathrm{C}=0.47-0.60$ \\
\hline Water storage & $251 / \mathrm{m}^{2}$ \\
\hline Ecological value & $\square \square \square \square \square$ \\
\hline Maintenance costs & $\square \square \square \square \square$ \\
\hline Cost factor & $\square \square \square \square \square$ \\
\hline
\end{tabular}

Optigreen Hydro-Seeding (Alternatively Dry Seeding): Optigreen Hydro-Seeding uses a special germinating substrate and a finely tuned Seed Mix Type E, consisting of numerous herbs (also grasses if desired) as well as various sedum shoots.

Optigreen Extensive Substrate Type E $(60 \mathrm{~mm})$ : A substrate with high water storage capacity and good air porosity, tailored to extensive multi layer systems.

Optigreen Combi Inspection Chamber (not shown in the drawing): Simple control of roof drainage outlets. Extendable in $100 \mathrm{~mm}$ increments. Side and top drainage openings. 
Optigreen Filter Fleece Type 105: Prevents fine particles from forming sludge in the drainage layer; high water permeability.

Optigreen Drainage Board Type FKD 25 (25 mm): Rapid discharge of surplus water. Prevents accumulation of water for non-pitched roofs and large drainage lengths. Light-weight build-up with high drainage capacity.

Optigreen Protection and Storage Fleece Type RMS 300: Protects the roof membrane against damage and stores water. For inverted roofs, use the Optigreen Trickle Protection Mat Type RS instead of the RMS fleece [5].

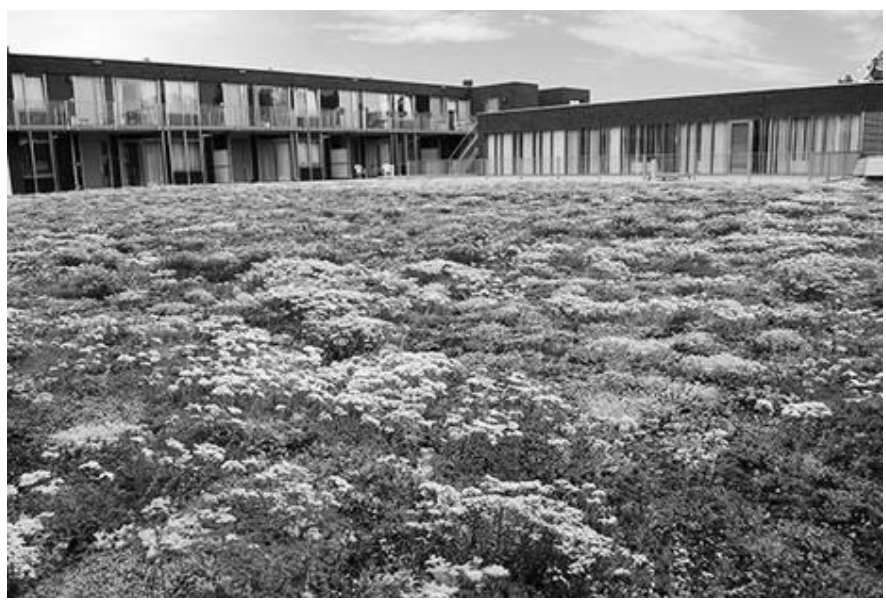

Fig. 4. Technical specifications of economy roof [5].

\section{NATURE ROOF}

TABLE V

NATURE ROOF LAYERS [6]

\begin{tabular}{|c|c|}
\hline 1 & Perennial plants and/or Optigreen Seed Mix Type E and Sedum \\
\hline 2 & Optigreen Extensive Substrate Type E $(60-200 \mathrm{~mm})$ \\
\hline 3 & Optigreen Filter Fleece Type 105 \\
\hline 4 & Optigreen Drainage Board Type FKD $40(40 \mathrm{~mm})$ \\
\hline 5 & Optigreen Protection and Storage Fleece Type RMS 300 \\
\hline 6 & Waterproofing membrane \\
\hline 7 & Suitable substructure \\
\hline
\end{tabular}

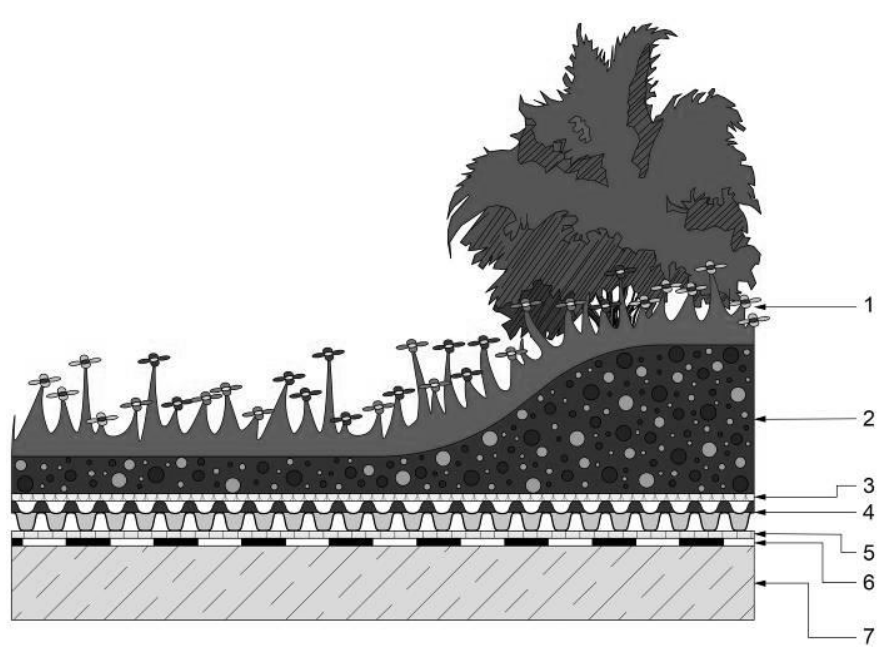

Fig. 5. Nature roof [6].
Features of nature roof in Fig.6: Multi-layered construction design using the Optigreen Drainage Board. High biodiversity of flora and fauna. Ecologically valuable green roofing. Habitat for butterflies and wild bees, among others. Longlasting and colorful blooming effect. Use of recycled plastic materials. Extensive and onefold intensive. Generally suitable for the inverted roof; if applicable, minimum load for the wind up-lift protection has to be considered. Weight specifications refer to the saturated conditions; dry weight is approximately 60-70 \% of the saturated weight. Discharge coefficient depends on the slope and system solution [6]. Roof layers in Fig.5 are described in Table $\mathrm{V}$ and its technical specifications are given in Table VI.

TABLE VI

NATURE ROOF TECHNICAL SPECIFICATIONS [6]

\begin{tabular}{|l|l|}
\hline Weight* & $100-300 \mathrm{~kg} / \mathrm{m}^{2}$ \\
\hline Layer height & $100-250 \mathrm{~mm}$ \\
\hline Roof pitch & $0-5^{\circ}(0-9 \%)$ \\
\hline Vegetation form & herbs-grasses-sedum \\
\hline Water retention & $60-70 \%$ \\
\hline Discharge coefficient & $\mathrm{C}=0.56-0.27$ \\
\hline Water storage & $30-801 / \mathrm{m}^{2}$ \\
\hline Ecological value & $\square \square \square \square \square$ \\
\hline Maintenance costs & $\square \square \square \square \square$ \\
\hline Cost factor & $\square \square \square \square \square$ \\
\hline
\end{tabular}

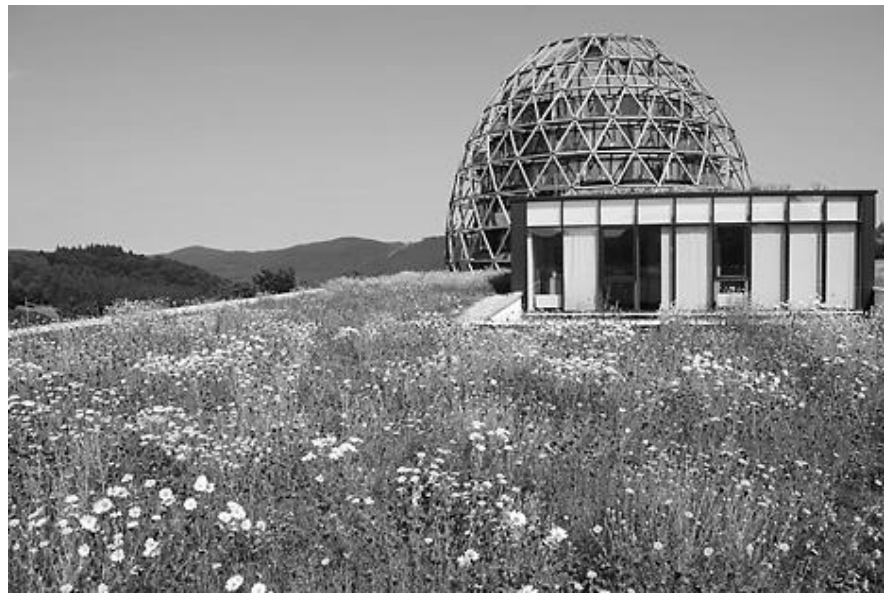

Fig. 6. Nature roof [6].

Perennial plants and/or Optigreen Seed Mix Type E and Sedum: Proven and specially-balanced seed mix consisting of a wide range of herbs and grasses (as desired) as well as numerous types of sedum shoots.

Optigreen Extensive Substrate Type E (60-200 mm): A substrate with high water storage capacity and good air porosity, tailored to extensive multi layer systems.

Mounds of up to $200 \mathrm{~mm}$, as required.

Optigreen Combi Inspection Chamber (not shown in the drawing): Simple control of roof drainage outlets. Extendable in $100 \mathrm{~mm}$ increments. Side and top drainage openings.

Optigreen Filter Fleece Type 105: Prevents fine particles from forming sludge in the drainage layer; high water permeability. 
Optigreen Drainage Board Type FKD 40 (40 mm): Rapid discharge of surplus water. Prevents accumulation of water for non-pitched roofs and large drainage lengths. Light-weight build-up with high drainage capacity. Vapor-permeable layer for tension reduction. Water storage.

Optigreen Protection and Storage Fleece Type RMS 300: Protects the roof membrane against damage and stores water. For inverted roofs use the Optigreen Trickle Protection Mat Type RS instead of the RMS Fleece [6].

\section{V.PITCHED ROOF A}

TABLE VII

PITCHED ROOF A LAYERS [7]

\begin{tabular}{|c|c|}
\hline 1 & Optigreen Pre-cultivated Sedum Vegetation Mat \\
\hline 2 & Optigreen Extensive Substrate Type E \\
\hline 3 & Optigreen Protection and Storage Fleece Type RMS 500 at ridge \\
\hline 4 & Optigreen Structured Storage Fleece Type SSV 800 at eaves \\
\hline 5 & Waterproofing membrane \\
\hline 6 & Suitable substructure \\
\hline
\end{tabular}

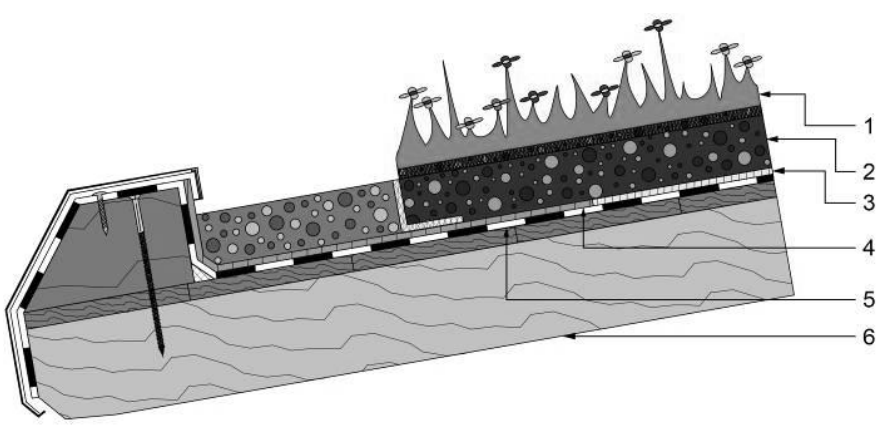

Fig. 7. Pitched roof A [7].

Features of pitched roof B in Fig.8: Permanent solution for green pitched roofs without a specialized Anti-Slip System. Suitable for roof lengths greater than $6 \mathrm{~m}$. Varied substrate depths and vegetation forms possible. Generally suitable for the inverted roof; if applicable, minimum load for the wind up-lift protection has to be considered. Anti-Slip Systems need to be used in case the roof pitch exceeds $15^{\circ}$. Weight specifications refer to the saturated conditions; dry weight is approximately $60-70 \%$ of the saturated weight. Discharge coefficient depends on the slope and system solution [7]. Roof layers in Fig.7 are described in Table VII and its technical specifications are given in Table VIII.

TABLE VIII

PITCHED ROOF A TECHNICAL SPECIFICATIONS [7]

\begin{tabular}{|l|l|}
\hline Weight & $100-130 \mathrm{~kg} / \mathrm{m}^{2}$ \\
\hline Layer height & $80-100 \mathrm{~mm}$ \\
\hline Roof pitch & $5-45^{\circ}(9-100 \%)$ \\
\hline Vegetation form & herbs-grasses-sedum \\
\hline Water retention & $40-60 \%$ \\
\hline Discharge coefficient & $\mathrm{C}=0.60-0.40$ \\
\hline Water storage & $351 / \mathrm{m}^{2}$ temporarily \\
\hline Ecological value & $\square \square \square \square \square$ \\
\hline Maintenance costs & $\square \square \square \square \square$ \\
\hline Cost factor & $\square \square \square \square \square$ \\
\hline
\end{tabular}

Optigreen Pre-cultivated Sedum Vegetation Mat: Precultivated sedum (herbs, grasses) mat for the fast establishment of vegetation, with rot-proof lining material.

Optigreen Extensive Substrate Type E: A substrate with high water storage capacity and good air porosity, tailored to pitched extensive systems.

Optigreen Protection and Storage Fleece Type RMS 500 at ridge: Protects the roof membrane against damage and stores water.

Optigreen Structured Storage Fleece Type SSV 800 at eaves: Suitable for water storage and targeted discharge of surplus water, especially at the eaves [7].

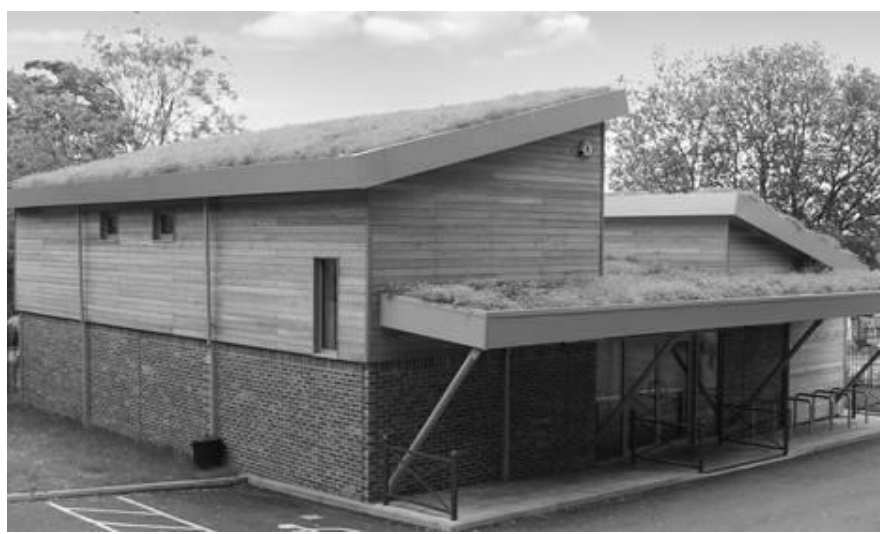

Fig. 8. Pitched roof A [7]

\section{PITCHED ROOF B \\ TABLE IX \\ PITCHED ROOF B LAYERS [8]}

\begin{tabular}{|c|c|}
\hline 1 & Optigreen Pre-cultivated Sedum Vegetation Mat \\
\hline 2 & Optigreen Extensive Substrate Type E $\left(701 / \mathrm{m}^{2}\right)$ \\
\hline 3 & Optigreen FKD 58 SD, drainage board for pitched roofs \\
\hline 4 & Slot for irrigation pipe \\
\hline 5 & Optigreen Protection and Storage Fleece Type RMS 500 \\
\hline 6 & Waterproofing membrane \\
\hline 7 & Suitable substructure \\
\hline
\end{tabular}

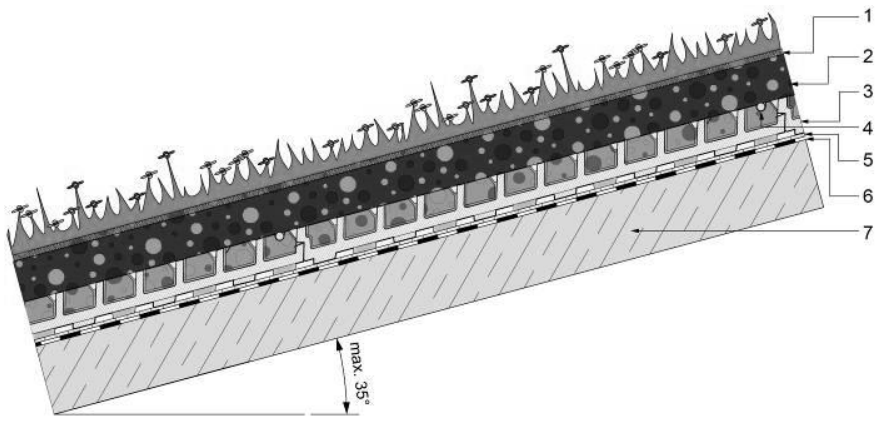

Fig. 9. Pitched roof B [8].

Features of pitched roof A in Fig.10: With Anti-Slip System. Shear stress distribution against the eaves. Affordable and safe Anti-Slip System. Permanent solution for green pitched roofs. Generally suitable for the inverted roof; if applicable, minimum load for the wind up-lift protection has to be considered. Weight specifications refer to the saturated conditions; dry weight is approximately 60-70\% of the 
saturated weight. Discharge coefficient depends on the slope and system solution [8]. Roof layers in Fig.9 are described in Table IX and its technical specifications are given in Table X.

TABLE $X$

PITCHED ROOF A TECHNICAL SPECIFICATIONS [8]

\begin{tabular}{|l|l|}
\hline Weight & $100-130 \mathrm{~kg} / \mathrm{m}^{2}$ \\
\hline Layer height & $80-100 \mathrm{~mm}$ \\
\hline Roof pitch & $15-35^{\circ}(9-100 \%)$ \\
\hline Vegetation form & herbs-grasses-sedum \\
\hline Water retention & $40-60 \%$ \\
\hline Discharge coefficient & $\mathrm{C}=0.60-0.40$ \\
\hline Water storage & $351 / \mathrm{m}^{2}$ temporarily \\
\hline Ecological value & $\square \square \square \square \square$ \\
\hline Maintenance costs & $\square \square \square \square \square$ \\
\hline Cost factor & $\square \square \square \square \square$ \\
\hline
\end{tabular}

Optigreen Pre-cultivated Sedum Vegetation Mat: Precultivated sedum (herbs, grasses) mat for the fast establishment of vegetation, with rot-proof lining material.

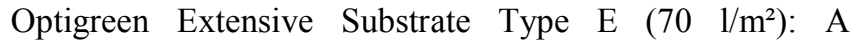
substrate with high water storage capacity and good air porosity, tailored to pitched extensive systems.

Optigreen FKD 58 SD, drainage board for pitched roofs: Prevents the green roof structure from slipping off and stabilizes the substrate layer.

Optigreen Protection and Storage Fleece Type RMS 500: Protects roof membrane against damage and stores water [8].
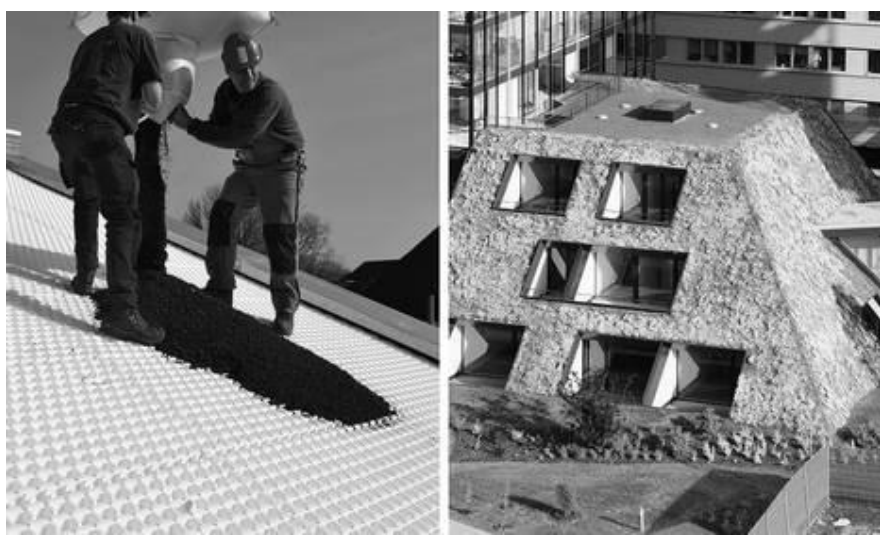

Fig. 10. Pitched roof B [8]

\section{RETENTION ROOF}

TABLE XI

RETENTION ROOF LAYERS [9]

\begin{tabular}{|c|c|}
\hline 1 & Perennial plants and/or Optigreen Seed Mix Type E \\
\hline 2 & Optigreen Extensive Substrate Type E $(60-90 \mathrm{~mm})$ \\
\hline 3 & Optigreen Filter Fleece Type 105 \\
\hline 4 & Temporary water reservoir \\
\hline 5 & Optigreen Meander Panel $60(60 \mathrm{~mm})$ \\
\hline 6 & Permanent water reservoir \\
\hline 7 & Optigreen Protection and Storage Fleece Type RMS 300 \\
\hline 8 & Waterproofing membrane \\
\hline 9 & Suitable substructure \\
\hline
\end{tabular}

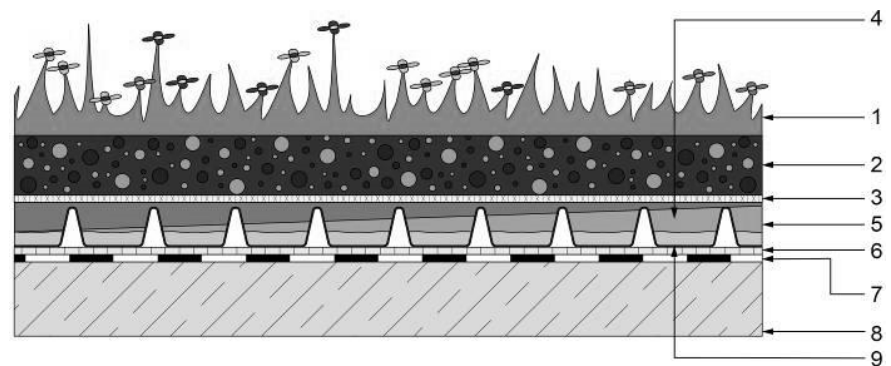

Fig. 11. Retention roof [9].

Features of retention roof in Fig.12: System solutions with defined water retention. High reduction of discharge peaks while retaining very good drainage. Water storage and discharge delay. Suitable for green roofs and ballasted roofs. Meander 60 prevents accumulation of water in cases of ponding of heights up to $40 \mathrm{~mm}$. Weight specifications refer to the saturated conditions; dry weight is approximately $60-70$ $\%$ of the saturated weight. Discharge coefficient depends on the slope and system solution [9]. Roof layers in Fig.11 are described in Table XI and its technical specifications are given in Table XII.

TABLE XII

RETENTION ROOF TECHNICAL SPECIFICATIONS [9]

\begin{tabular}{|l|l|}
\hline Weight & $120-140 \mathrm{~kg} / \mathrm{m}^{2}$ \\
\hline Layer height & $120 \mathrm{~mm}$ \\
\hline Roof pitch & $0-5^{\circ}(0-9 \%)$ \\
\hline Vegetation form & herbs-grasses-sedum \\
\hline Water retention & $>80 \%$ \\
\hline Discharge coefficient & $\mathrm{C}=0.05-0.17$ \\
\hline Water storage & $38-531 / \mathrm{m}^{2}$ temporarily \\
\hline Ecological value & $\square \square \square \square \square$ \\
\hline Maintenance costs & $\square \square \square \square \square$ \\
\hline Cost factor & $\square \square \square \square \square$ \\
\hline
\end{tabular}

Perennial plants and/or Optigreen Seed Mix Type E: Proven and specially-balanced seed mix consisting of a wide range of herbs and grasses (as desired) as well as numerous types of sedum shoots.

Optigreen Extensive Substrate Type E (60 - $90 \mathrm{~mm})$ : A substrate with high water storage capacity and good air porosity, tailored to extensive multi layer systems.

Optigreen Combi Inspection Chamber (not shown in the drawing): Simple control of roof drainage outlets. Extendable in $100 \mathrm{~mm}$ increments. Side and top drainage openings.

Optigreen Filter Fleece Type 105: Prevents fine particles from forming sludge in the drainage layer; high water permeability.

Optigreen Meander Panel 60 (60 mm): Strong delay of discharge of surplus water. Prevents accumulation of water for non-pitched roofs and large drainage lengths. High retention as well as high drainage capacity.

Optigreen Protection and Storage Fleece Type RMS 300: Protects the roof membrane against damage and stores water. For inverted roofs, use the Optigreen Trickle Protection Mat Type RS instead of the RMS fleece [9]. 


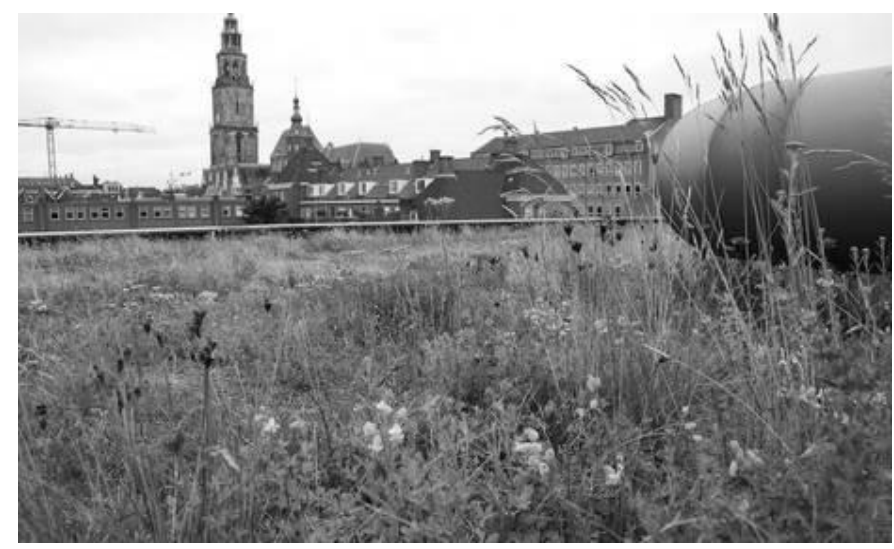

Fig. 12. Retention roof [9].

\section{VIII.BLUE - GREEN ROOF PERFORMANCE DATA}

Michael Van Valkenburgh has created a little $130 \mathrm{~m}^{2}$ green roof for the building of the American Society of Landscape Architects in the heart of Washington D.C that was installed in April 2006. The project was undertaken with the goals of demonstrating the environmental and aesthetic benefits of green roofs. Processes that are being monitored are: process to track stormwater retention, temperature, water quality and plant performance. Here are presented ceratin extensive and semi-intensive green roof performance data from full report [10].

Water retention: between July, 2007 and May, 2007 the green roof retained nearly $75 \%$ of the total rainfall $(736 \mathrm{~mm})$. This kept 105,000 liters out of the city sewer system. The roof typically retained $100 \%$ of $(25 \mathrm{~mm})$ rainfall. Water quality: The roof did not add any nitrogen to the runoff. Water quality testing shows that the water runoff contains fewer pollutants than typical water runoff. Most significantly, the roof is reducing the amount of nitrogen entering the watershed [11].

\section{CONCLUSIONS}

Water storage of each roof discussed is given in liter per 1 $\mathrm{m}^{2}$. The aim of this article was to show the ability of different roofs to catch water, to point at discharge coefficient and water storage of each named roof. Exemplary $1 \mathrm{~m}^{2}$ given in Table XIII is recalculated into $100 \mathrm{~m}^{2}$, which could represent a roof of one single family house.

The question this article addresses is what effect would green - blue roofs have on our cities, buildings, environment, lives, and health. How much water would we be able to keep above our heads and what would be the possibilities for us at present and for the future generations.

Example of the green roof in the building of the American Society of Landscape Architects shows water performance data such as water retention and water quality. The example points out how much water the green roof retained of the total rainfall. This example of built green roof shows, how much water is kept out of the city sewer system.
TABLE XIII

WATER STORAGE

\begin{tabular}{|c|c|c|}
\hline ROOF & $1 / 1 \mathrm{~m}^{2}$ & $1 / 100 \mathrm{~m}^{2}$ \\
\hline Lightweight & 18 & 1800 \\
\hline Economy & 25 & 2500 \\
\hline Nature & $30-80$ & $3000-8000$ \\
\hline Pitched A & 35 & 3500 \\
\hline Pitched B & 35 & 3500 \\
\hline Retention & $38-53$ & $3800-5300$ \\
\hline
\end{tabular}

The aim of this article was to analyse different types of possible roofs with the focus on their ability to catch water. The most important issue what implications these liters of water per 1 single family house may have in the future: retaining water of the total rainfall, keeping water out of the city sewer system and reducing the amount of nitrogen entering the watershed.

\section{ACKNOWLEDGEMENTS}

This work was supported by: VEGA 1/0202/15 Bezpečné a udržatel'né hospodárenie s vodou v budovách tretieho milénia/ Sustainable and Safe Water Management in Buildings of the 3rd. Millennium.

\section{REFERENCES}

[1] P. Jodidio, Green architecture now!. Taschen: Cologne, 2009, pp. 6-18.

[2] K. Yeang, A. Spector, Green design. From theory to practice. Black dog publishing: London, 2011, pp. 7-12.

[3] N. Dunnett et al., Small green roofs. Timber press: Portland*London, 2011, pp.8-13.

[4] Lightweight roof Solution 1: $0-5^{\circ}$ [Online]. Available: http://www. optigreen.com/systemloesungen/leichtdach/loesung-1/ [Accessed
[A November 10, 2014].

[5] Economy roof Solution 1(using drainage board): $0-5^{\circ}$ [Online]. Available: http://www.optigreen.com/systemloesungen/spardach/ loesung-1/ [Accessed November 10, 2014].

[6] Nature roof Solution 1 (using drainage board): $0-5^{\circ} \mathrm{http}: / / \mathrm{www}$. optigreen.com/systemloesungen/naturdach/loesung-1/[Accessed November 10, 2014]

[7] Pitched roof $5-15^{\circ}$ (without antislip system) http://www.optigreen.com/ systemloesungen/schraegdach/5-15/ [Accessed November 10, 2014]. [Accessed November 10, 2014].

[8] Pitched roof Type P (board) $15-35^{\circ}$ (with antislip system) http://www. optigreen.com/systemloesungen/schraegdach/15-35-typ-p-platte/ [Accessed November 10, 2014].

[9] Retention roof Meander $60 \mathrm{http} / / / \mathrm{www}$. optigreen.com/system-solutions/ retention-roof/meander-60/ [Accessed November 10, 2014].

[10] ASLA headquarters green roof. http://www.asla.org/uploadedFiles/ CMS/Green_Roof/ SustainabilityWithStyle.pdf (2014-01-09)

[11] N. Somerville et al., "Sustainability with style: The ASLA headquarters green roof" [Online]. Available: http://www.asla.org/uploadedFiles/ CMS/Green_Roof/SustainabilityWithStyle.pdf [Accessed November 10, 2014]. 